\title{
Mapa de tendencias en Innovación Educativa
}

\section{Map of trends in educational innovation}

\section{Francisco José García-Peñalvo}

Departamento de Informática y Automática, Instituto de Ciencias de la Educación, Grupo GRIAL, Director Científico, Editor-In-Chief Education in the Knowledge Society Journal, Universidad de Salamanca, España. fgarcia@usal.es

En el III Congreso Internacional sobre Aprendizaje, Innovación y Competitividad, CINAIC 2015, celebrado entre el 14 y el 16 de octubre de 2015 en Madrid (Fidalgo Blanco, Sein-Echaluce Lacleta, \& GarcíaPeñalvo, 2015a), tuve la ocasión de impartir una conferencia plenaria sobre las actuales tendencias en la innovación educativa (García-Peñalvo, Fidalgo Blanco, \& Sein-Echaluce Lacleta, 2015).

Ante un reto como este la primera dificultad es organizar la enorme cantidad de información que se podría abordar, para así intentar dar coherencia al discurso de la conferencia.

Como punto de partida se ha tomado la definición que de Innovación Educativa se había establecido en el seno de la propia comunidad CINAIC: "Realizar cambios en el aprendizaje/formación que produzcan mejoras en los resultados de aprendizaje. Sin embargo, para que se considere innovación educativa el proceso debe responder a unas necesidades, debe ser eficaz y eficiente, además de sostenible en el tiempo y con resultados
In last edition of the III Congreso Internacional sobre Aprendizaje, Innovación y Competitividad, CINAIC 2015, held in Madrid in October 1416, 2015 (Fidalgo Blanco, Sein-Echaluce Lacleta, \& García-Peñalvo, 2015a), I had the opportunity to give a keynote speech about the current trends in educational innovation (García-Peñalvo, Fidalgo Blanco, \& Sein-Echaluce Lacleta, 2015).

Given a challenge like this, the first difficulty is toorganizeheenormousamount of information that could be addressed in order to try to bring coherence to the speech of the speech.

As a starting point is taken the definition of Educational Innovation that was established within the CINAIC community: "Making changes to the learning/training process to produce improvements in the learning outcomes. However, to be considered as educational innovation, the process needs to respond to needs, should be effective and efficient, plus being sustainable over time and with transferable 
transferibles más allá del contexto particular donde surgieron" (Sein-Echaluce Lacleta, Fidalgo Blanco, \& García-Peñalvo, 2014).

De esta definición se obtiene que lo que realmente supone una innovación educativa es una suma sinérgica entre crear algo nuevo, el proceso en el que se aplica y la aportación de una mejora como resultado del proceso, y todo ello con una dependencia del contexto en el que se desarrolla y aplica la supuesta innovación.

Una vez que ha quedado claro el propósito de la innovación educativa, el siguiente paso es conocer qué se está considerando como innovación educativa y cómo se está clasificando. Los repositorios institucionales (Fernández-Pampillón Cesteros, Domínguez Romero, \& Armas Ranero, 2013; GarcíaPeñalvo et al., 2010; López, García-Peñalvo, \& Pernías, 2005; Morales, Gil, \& GarcíaPeñalvo, 2007; Morales, Gómez-Aguilar, \& García-Peñalvo, 2008) contienen la radiografía de los tópicos que se están considerando actualmente en los proyectos de innovación educativa. Sin embargo, en estos repositorios los datos sobre innovación educativa no suelen ser fácil de localizar por compartir espacio con otra mucha información institucional. Por ello se ha partido del repositorio de buenas prácticas de innovación docente financiado por el Ministerio de Educación del Gobierno de España (Fidalgo-Blanco, 2012) y más concretamente de la implantación de dicho results beyond the particular context in which emerged" (Sein-Echaluce Lacleta, Fidalgo Blanco, \& García-Peñalvo, 2014).

From this definition we obtain that educational innovation really is the synergic add of creating something new, the process in which this new product is applied and its contribution as an improvement of that process application, and all of this independently of the context in which the innovation is developed and applied.

Once it has become clear that the purpose of educational innovation, the next step is to know what is being considered as educational innovation and how it is classified. Institutional repositories (Fernández-Pampillón Cesteros, Domínguez Romero, \& Armas Ranero, 2013; García-Peñalvo et al., 2010; López, GarcíaPeñalvo, \& Pernías, 2005; Morales, Gil, \& García-Peñalvo, 2007; Morales, GómezAguilar, \& García-Peñalvo, 2008) contain the radiography of the topics currently are being considered in educational innovation projects. However, in these repositories the data about the educational innovation projects are not easy to achieve because of they share the space with a huge quantity of institutional information of different nature. Thus, we start from a specialized repository in educational innovation good practices (Fidalgo-Blanco, 2012) that was financed by the Spanish Ministry of Education and more specifically from the implantation of this repository in the University of 
repositorio en la Universidad de Salamanca (García-Peñalvo, Sein-Echaluce Lacleta, \& Fidalgo-Blanco, 2015) y en la Universidad de Zaragoza (Abadía et al., 2015), ambos basados en el buscador BRACO (Fidalgo Blanco, Sein-Echaluce Lacleta, GarcíaPeñalvo, \& Pinilla-Martínez, 2015).

Además, se han tenido en cuenta los trabajos para definir indicadores que faciliten la clasificación y búsqueda de experiencias de innovación educativa (Fidalgo-Blanco, Balbín, Lerís, \& Sein-Echaluce, 2011; Fidalgo-Blanco, Lerís, Sein-Echaluce, \& García-Peñalvo, 2013; Fidalgo-Blanco \& Ponce, 2011; Fidalgo-Blanco, Sein-Echaluce Lacleta, Lerís, \& García-Peñalvo, 2013; Fidalgo-Blanco, Sein-Echaluce, \& GarcíaPeñalvo, 2014, 2015; Sein-Echaluce Lacleta, Fidalgo-Blanco, García-Peñalvo, \& CondeGonzález, 2015; Sein-Echaluce, Lerís, Fidalgo-Blanco, \& García-Peñalvo, 2013).

Como resultado se ha definido una ontología de indicadores para la innovación docente (García-Peñalvo, Sein-Echaluce Lacleta, et al., 2015). De sus diferentes dimensiones nos interesa centrarnos en el contexto del Aprendizaje que se organiza en cuatro características:

1. Actividad.

2. Tecnología.

3. Métodos y técnicas.

4. Resultados.

Con toda esta información se ha realizado una abstracción de las tendencias en Innovación
Salamanca (García-Peñalvo, Sein-Echaluce Lacleta, \& Fidalgo-Blanco, 2015) and in the University of Zaragoza (Abadía et al., 2015), both based on BRACO engine (Fidalgo Blanco, Sein-Echaluce Lacleta, García-Peñalvo, \& Pinilla-Martínez, 2015).

Moreover, other works that define indicators to classify and search educational innovation experiences have been taken into account (Fidalgo-Blanco, Balbín, Lerís, \& SeinEchaluce, 2011; Fidalgo-Blanco, Lerís, SeinEchaluce, \& García-Peñalvo, 2013; FidalgoBlanco \& Ponce, 2011; Fidalgo-Blanco, Sein-Echaluce Lacleta, Lerís, \& GarcíaPeñalvo, 2013; Fidalgo-Blanco, Sein-Echaluce, \& García-Peñalvo, 2014, 2015; Sein-Echaluce Lacleta, Fidalgo-Blanco, García-Peñalvo, \& Conde-González, 2015; Sein-Echaluce, Lerís, Fidalgo-Blanco, \& García-Peñalvo, 2013).

As result we have defined an ontology of indicators for educational innovation (García-Peñalvo, Sein-Echaluce Lacleta, et al., 2015). We are going to focus on in its dimension of Learning Context, which is organized in four characteristics: 1. Activity.

2. Technology.

3. Methods and techniques.

4. Outcomes.

With this information we have defined an abstractionmodelwiththetrendsineducational innovation based on a map metaphor divided in four non disjoint regions (see Figure 2): 1. Institutional perspective. It is the region 
Educativa en forma de mapa que se organiza en cuatro regiones no disjuntas (ver Figura 1):

1. Perspectiva institucional. Es la región del mapa que va a recoger las tendencias más relacionadas con la toma de decisiones, planificación estratégica, gestión de la tecnología y gestión de la propia innovación.

2. Perspectiva del profesorado. Es la región del mapa más cercana al contexto del profesor y su docencia, es decir, en la que se van a volcar todas aquellas innovaciones que tienen un carácter más ligado a la impartición de los contenidos curriculares.

3. Desarrollo de competencias transversales. Es la región del mapa en la que se potencian las competencias transversales, muy ligadas a las denominadas habilidades blandas (soft skills) que tanta importancia tienen en el mercado laboral y en el desarrollo más humanista de los estudiantes.

4. Perspectiva de extensión institucional. Es la región del mapa en la que se desarrollan los aspectos más novedosos que tienen que ver con la labor de extensión hacia la sociedad y la formación permanente.

Sin pretender ser exhaustivos ni mucho menos categóricos, en la Figura 1 se pueden apreciar tópicos ubicados en cada región que ilustran algunas de las tendencias de mayor difusión en las conferencias y revistas especializadas, así como en las temáticas de los proyectos de innovación educativa consultados en los repositorios. Es importante destacar que of the map that gathers the more related trends with the decision-making processes, the strategic planning, the management of the technology and the management of the educational innovation.

2. Faculty perspective. This is the nearest region of the map to the teacher's context. It reflects all the innovations that are linked to the contents of the subjects they teach.

3. Transversal competences development. It is the region of the map that powers the transversal competences and soft skills that have a very important role in both the workplace and the humanist development of the students.

4. Institutional extension perspective. It is the region of the map in which the most innovative aspects related to the extension of the education mission towards society and lifelong learning education are developed.

Without being exhaustive, much less categorical, Figure 2 shows the different topics, located in each region of the map, that represent some of the most widespread trends in the specialized conferences and journals, also in the focus of the educational innovation projects that may be consulted in the repositories. It is also important to emphasize that in the different intersections among the regions appear interesting trends that combine the main characteristics of the affected zones.

We do not seek to make a review, by 
en las diferentes intersecciones entre las regiones representadas se localizan también interesantes tendencias que combinan características de las zonas afectadas. No se buscar hacer una revisión, por somera quefuera, detodas y cada una de las tendencias identificadas en el mapa, pero a modo de ejemplo se van mencionar algunas de ellas.

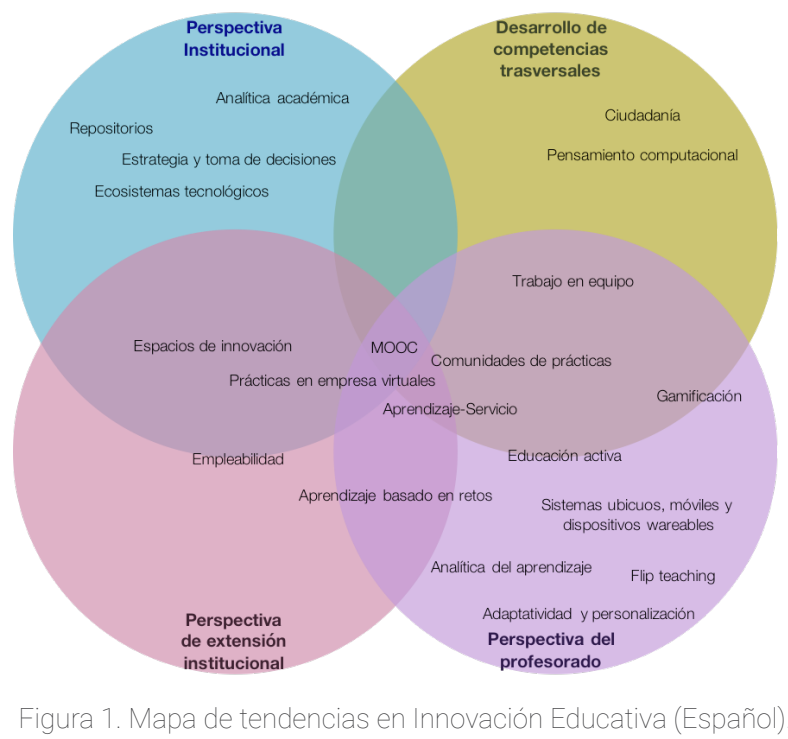

En la región de perspectiva institucional se puede destacar como tendencia de la gestión de la tecnología, y también del conocimiento, el concepto de ecosistema tecnológico (García-Holgado \& García-Peñalvo, 2013, 2014; García-Holgado, García-Peñalvo, Hernández-García, \& Llorens-Largo, 2015) que se define como "comunidad, con métodos educativos, políticas, reglamentos, aplicaciones y equipos de trabajo, que puede coexistir de manera que sus procesos están interrelacionados y su aplicación se basa en los factores físicos del entorno tecnológico" (Llorens, Molina, Compañ, \& Satorre, 2014). Un ecosistema tecnológico viene a plantear una arquitectura flexible y adaptativa shallow it was, of each and every one of the identified trends in the map, but for example, we will mention some of them. In the region of Institutional Perspective it is interesting to underline the Information Technology Government and, of course, the knowledge management issue, thus quite

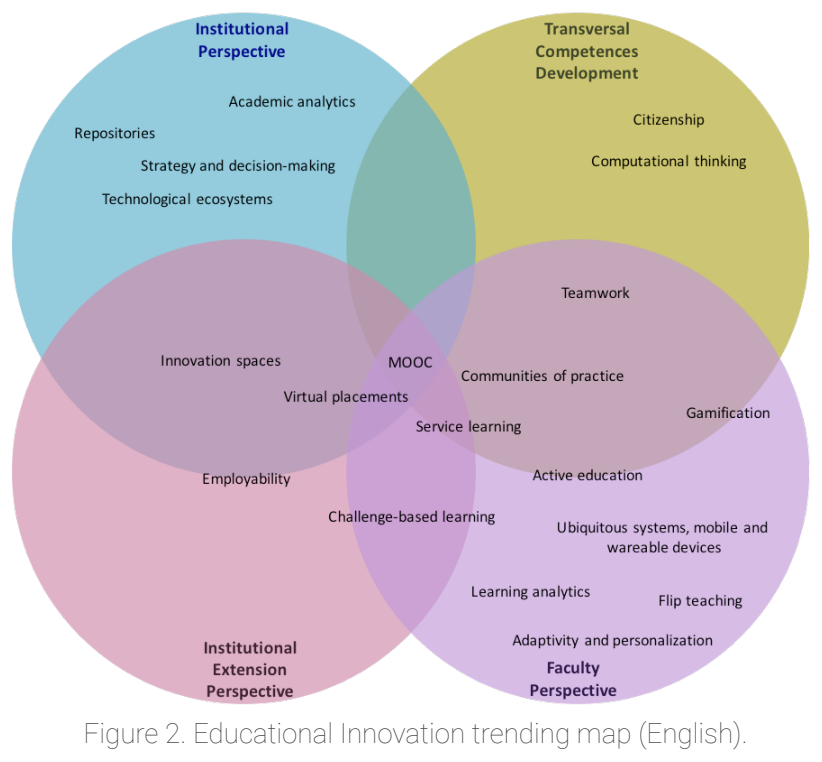

related to these notions the technological ecosystems trends appear (García-Holgado \& García-Peñalvo, 2013, 2014; García-Holgado, García-Peñalvo, Hernández-García, \& Llorens-Largo, 2015), which may be defined as "community -with its own educative methods, policies, regulations, applications, and team works- that may coexist by the way that its processes are interrelated and its application is based on in the physical factors of the technological environment" (Llorens, Molina, Compañ, \& Satorre, 2014). A technological ecosystem proposes a flexible and adaptive architecture (GarcíaPeñalvo, Hernández-García, et al., 2015a, $2015 b)$ in order to support the evolution of its components and their interconnections to 
(García-Peñalvo, Hernández-García, et al., 2015a, 2015b) para soportar la evolución de los componentes y sus interconexiones para conseguir una interoperabilidad transparente entre ellos (Alier Forment, Casany Guerrero, Conde González, GarcíaPeñalvo, \& Severance, 2010), de manera que se busca acabar con el reinado monolítico de las plataformas de aprendizaje o Learning Management Systems (LMS), que pasan de ser sistemas aislados a ser un componente más dentro del ecosistema (Conde et al., 2014).

El concepto de analítica académica se refiere a las prácticas de toma de decisiones basadas en los datos con fines operativos en el nivel institucional (Baepler \& Murdoch, 2010), pero esta misma idea de toma de decisiones pero relacionada con la perspectiva del profesor, por su vinculación al proceso de enseñanza/aprendizaje, nos llevaría al concepto de analíticas del aprendizaje (Gómez-Aguilar, García-Peñalvo, \& Therón, 2014; Gómez-Aguilar, HernándezGarcía, García-Peñalvo, \& Therón, 2015), que además podrían servir como soporte para otra de las tendencias que se dan en la región del profesorado, la adaptatividad y la personalización del aprendizaje (Berlanga \& García-Peñalvo, 2004, 2005a, 2005b, 2008; Lerís \& Sein-Echaluce, 2011). Para muchos autores una de las innovaciones disruptivas más importantes en educación se produjo en 1999 de la mano de las tecnologías online (García-Peñalvo \& Seoane-Pardo, 2015) porque permitieron allow a transparent interoperability among them (Alier Forment, Casany Guerrero, Conde González, García-Peñalvo, \& Severance, 2010). This technological metaphor is looking for to avoid with the Learning Management Systems (LMS) monolithic approach, which pass to be isolated systems to be one component at the same level of the rest within the ecosystem (Conde et al., 2014).

Academic analytics notion refers to the decision-making practices based on operational data in the institutional level (Baepler \& Murdoch, 2010). The same idea but related to the teacher's perspective in the teaching/learning processes means the learning analytics concept (Gómez-Aguilar, García-Peñalvo, \& Therón, 2014; GómezAguilar, Hernández-García, García-Peñalvo, \& Therón, 2015), besides these analytics techniques could be the support for other trend that appears in the faculty region of the map, the learning adaptivity and personalization (Berlanga \& García-Peñalvo, 2004, 2005a, 2005b, 2008; Lerís \& Sein-Echaluce, 2011).

Many authors have the opinion that one of the disruptive innovations more important in education was in 1999 throughout the online (García-Peñalvo \& Seoane-Pardo, 2015) technologies because of they allowed many people have access to education facilities that otherwise would not be possible (Weise \& Christensen, 2014). Nowadays, the question is if Massive Open Online Courses (MOOC), placed at the intersection of the four 
que muchas personas pudieran acceder a una educación que de otra forma no hubiera sido posible (Weise \& Christensen, 2014). La cuestión viene ahora en determinar si los Massive Open Online Courses (MOOC), colocados en la intersección de las cuatro regiones del mapa, constituyen o no una nueva innovación disruptiva. Hay opiniones en todos los sentidos (Cabero, 2015; Christensen \& Weise, 2014; Farmer, 2013; Salzberg, 2015), aunque admitiendo que los MOOC han supuesto una importante renovación en el panorama de la formación online, todavía les queda camino por alcanzar la madurez y la influencia necesaria en el tejido social para alcanzar el estado de disruptivos. No obstante, los MOOC plantean interesantes retos desde el punto de vista de la innovación educativa, tal y como explorar la adaptatividad y personalización (Fidalgo Blanco, García-Peñalvo, \& SeinEchaluce Lacleta, 2013; Sonwalkar, 2013); explorar diseños mixtos que incorporen la cooperación gracias al uso intensivo de las redes sociales como estrategia de aprendizaje (Fidalgo, Sein-Echaluce Lacleta, \& García-Peñalvo, 2013; Fidalgo Blanco, Sein-Echaluce Lacleta, \& García-Peñalvo, 2015b); la creación de comunidades de aprendizaje (Alario-Hoyos et al., 2013); la utilización de entornos personalizados de aprendizaje (PLE) (Castaño Garrido, Maiz, \& Garay Ruiz, 2015); o explorar la gamificación (Borrás Gené, Martínez Núñez, \& Fidalgo Blanco, 2014; Borrás-Gené, Martínez-Nuñez, \& Fidalgo Blanco, 2015). regions of the map, constitute or not a new disruptive innovation. There are opinions in all the possible directions (Cabero, 2015; Christensen \& Weise, 2014; Farmer, 2013; Salzberg, 2015); although admitting that MOOC have meant a major renovation in the landscape of online training, still they are far to reach the maturity and the necessary influence on the society to achieve the status of disruptive. However, MOOC pose interesting challenges from the point of view of educational innovation, as exploring the adaptivity and personalization (Fidalgo Blanco, García-Peñalvo, \& Sein-Echaluce Lacleta, 2013; Sonwalkar, 2013); defining hybrid designs that introduce cooperation through an intensive usage of the social networks as learning strategy (Fidalgo, SeinEchaluce Lacleta, \& García-Peñalvo, 2013; Fidalgo Blanco, Sein-Echaluce Lacleta, \& García-Peñalvo, 2015b); creating learning communities (Alario-Hoyos et al., 2013); using Personal Learning Environments (PLE) (Castaño Garrido, Maiz, \& Garay Ruiz, 2015); or probing gamification issues (Borrás Gené, Martínez Núñez, \& Fidalgo Blanco, 2014; Borrás-Gené, Martínez-Nuñez, \& Fidalgo Blanco, 2015).

The idea of the virtual placements or internships in enterprises, companies and foundations is a trend that is located in the Institutional Extension region of the map with an important intersection with the others zones. This kind of placement seeks to exploit the opportunities offered by the 
El concepto de prácticas virtuales en empresas es una tendencia que se ubica en la región de extensión institucional con una clara intersección con el resto de las zonas del mapa. Buscan aprovechar las oportunidades que ofrecen las tecnologías para facilitar una práctica profesional en una empresa por parte de estudiantes en un régimen de teletrabajo, con lo que se consiguen todos los beneficios de una estancia en una empresa, con independencia de su localización geográfica, sin tener los costes asociados a tener que desplazarse a la ciudad donde se ubica la misma. Un ejemplo de prácticas virtuales de estudiantes de Ingeniería en Informática en empresas relacionadas con el desarrollo de open software es el proyecto europeo Virtual Alliances for Learning Society (VALS) (García-Peñalvo, 2015; GarcíaPeñalvo, Cruz-Benito, Conde, \& Griffiths, 2014, 2015; García-Peñalvo, Cruz-Benito, Griffiths, \& Achilleos, 2015a, 2015b; GarcíaPeñalvo, Cruz-Benito, Griffiths, et al., 2014).

Para concluir este repaso por algunas de las tendencias en innovación educativa se va a elegir una ubicada en la zona de desarrollo de competencias transversales como es el desarrollo del pensamiento computacional que consiste en la resolución de problemas, el diseño de los sistemas, y la comprensión de la conducta humana haciendo uso de los conceptos fundamentales de la informática (Wing, 2006). Según Zapata-Ros (2015) los componentes del pensamiento computacional son: el análisis ascendente y descendente, technologies to facilitate the professional practice in an institution using a tele-work approach; achieving all the benefits of a typical internship, but independently of its geographic location and without having the associated cost of changing the city where the students live. An example of virtual placements for Informatics Engineering in open software development companies is the European project Virtual Alliances for Learning Society (VALS) (García-Peñalvo, 2015; GarcíaPeñalvo, Cruz-Benito, Conde, \& Griffiths, 2014, 2015; García-Peñalvo, Cruz-Benito, Griffiths, \& Achilleos, 2015a, 2015b; GarcíaPeñalvo, Cruz-Benito, Griffiths, et al., 2014).

In order to close this overview over some of the trends in educational innovation we are going to select one placed in the Transversal Competences Development zone, specifically the computational thinking improvement, which is devoted to solve problems, design systems, and understand the human behaviour using the main fundaments from Computer Science (Wing, 2006). ZapataRos (2015) states that computational thinking core components are: the upstream and downstream analysis, heuristics, divergent thinking, creativity, problem solving, abstract thinking, recursion, iteration, successive approximation methods, collaborative methods, patterns, the synectics and metacognition.

After doing the quick review of the trends set, just like a sample of what is happening 
las heurísticas, el pensamiento divergente, la creatividad, la resolución de problemas, el pensamiento abstracto, la recursividad, la iteración, los métodos por aproximaciones sucesivas, los métodos colaborativos, los patrones, la sinéctica y la metacognición.

Tras esta revisión de un conjunto de tendencias, como muestra de lo que se está haciendo en innovación educativa en un ámbito global, como conclusión general se podría decir que la innovación educativa tiene múltiples perspectivas que se complementan, pero lo realmente importante es que ante un mundo en continuo cambio y evolución, el profesorado mantenga la inquietud por innovar en sus procesos con el fin de mejorar el aprendizaje de las personas.

\section{Contenidos del número}

Este último número del volumen 16 está conformado por la sección especial "Informática Educativa y Educación en Informática" editada por José Luis SierraRodríguez y Francisco José García Peñalvo (2015) y que se compone de cuatro artículos seleccionados y extendidos presentados en la decimosexta edición del Simposio Internacional de Informática Educativa (SIIE 2014), celebrado entre el 12 y el 14 de noviembre de 2014 en Logroño, La Rioja, España (Sierra Rodríguez, Dodero Beardo, \& Burgos, 2014a, 2014b).

Además, se incluyen en este número tres artículos regulares y recensión de la tesis in the educational innovation in a global scope, the main conclusion we may say that educational innovation has several complementary perspectives, but what really matters is that in a world in constant change and evolution, teachers keep the concern to innovate in their processes with the aim to improve the learning of the people.

\section{Contents of the issue}

This last issue of volume 16 is composed by a special section entitled "Computers in Education and Education in Computer Science" edited by José Luis Sierra-Rodríguez and Francisco José García Peñalvo (2015) including four selected and extended papers from sixteenth edition of the International Symposium in Computers in Education (SIIE 2014), held in Logroño, La Rioja, Spain on November 12-14, 2014 (Sierra Rodríguez, Dodero Beardo, \& Burgos, 2014a, 2014b).

Besides, this issue presents three regular papers and a review of the $\mathrm{PhD}$ entitled Adaptación de la legislación a la Residencia "Gregorio Santiago" de Burgos de 1990 a 2000 by Rafael Calvo de León (2015).

With regard to the regular papers published in this issue, the first one is entitled "Providing pervasive Learning eXperiences by Combining Internet of Things and e-Learning standards" by Aroua Taamallah and Maha Khemaja (2015). This paper aims to take advantage of this trend and keep up also with existing e-Learning standards such 
doctoral Adaptación de la legislación a la Residencia "Gregorio Santiago" de Burgos de 1990 a 2000 realizada por Rafael Calvo de León (2015).

En cuanto a los artículos regulares publicados en este número, el primero de ellos lleva por título "Providing pervasive Learning eXperiences by Combining Internet of Things and e-Learning standards" $\mathrm{y}$ ha sido realizado por Aroua Taamallah y Maha Khemaja (2015). En este trabajo propone extender los modelos de normas de aprendizaje electrónico como IMS LD y LOM para soportar Internet de las Cosas y para aportar un enfoque de adaptación de las actividades de aprendizaje según el contexto del estudiante y su huella digital utilizando la API eXperience.

El siguiente artículo "APPrender a leer y escribir: aplicaciones para el aprendizaje de la lectoescritura" ha sido realizado por Raquel Gómez-Díaz y Araceli García-Rodríguez (2015). Este artículo se centra en las apps destinadas al aprendizaje de la lectoescritura, y ofrece, además de una tipología de las mismas, y una selección de algunas de ellas.

En el tercer y último artículo, que lleva por título "Aprendizaje adaptativo en Moodle: Tres casos prácticos" y ha sido realizado por Dolores Lerís López et al. (2015), se revisan las funcionalidades adaptativas disponibles en Moodle. Se explica cómo se han puesto en práctica tres casos de diseños instruccionales as IMS LD and LOM. The solution proposed is therefore to extend these standards models with that of Internet of Things and to provide an adaptation approach of learning activities based on learner's context and her/his track using the eXperience API.

Next paper "Learn to read and write: app for the literacy learning" by Raquel GómezDíaz and Araceli García-Rodríguez (2015). This paper is centred on the apps intended for literacy learning, and offers, along with a typology, and a selection of some of them.

In the third and last paper, which is entitled "Adaptive learning in Moodle: Three practical cases" by Dolores Lerís López et al. (2015), the Moodle adaptivity capabilities are reviewed. Moreover, authors explain how to implement three adaptive instructional designs in Moodle. Also, it is checked their effectiveness, in terms of the learning achieved by the student, and their efficiency, by reusing materials of previous learning experiences. 
adaptativos. Además, se constata su eficacia, en términos del aprendizaje logrado por el estudiante, y su eficiencia, al reutilizar materiales de experiencias anteriores.

\section{Referencias}

Abadía, A. R., Beltrán, F., Bueno, C., Fidalgo Blanco, Á., Julián, J. A., Lerís, D., . . . SeinEchaluce Lacleta, M. L. (2015). Repositorio de Buenas Prácticas de Innovación Docente de la Universidad de Zaragoza. In Á. Fidalgo Blanco, M. L. Sein-Echaluce Lacleta, \& F. J. García-Peñalvo (Eds.), La Sociedad del Aprendizaje. Actas del III Congreso Internacional sobre Aprendizaje, Innovación y Competitividad. CINAIC 2015 (14-16 de Octubre de 2015, Madrid, España) (pp. 761766). Madrid, Spain: Fundación General de la Universidad Politécnica de Madrid.

Alario-Hoyos, C., Pérez-Sanagustín, M., Delgado-Kloos, C., Parada G, H., MuñozOrganero, M., \& Rodríguez-de-las-Heras, A. (2013). Analysing the Impact of Built-In and External Social Tools in a MOOC on Educational Technologies. In D. HernándezLeo, T. Ley, R. Klamma, \& A. Harrer (Eds.), Scaling up Learning for Sustained Impact (Vol. 8095, pp. 5-18): Springer Berlin Heidelberg.

Alario-Hoyos, C., Pérez-Sanagustín, M., Delgado-Kloos, C., Parada, H. A., MuñozOrganero, M., \& Rodríguez-de-las-Heras, A. (2013). Analysing the Impact of Built-In and External Social Tools in a MOOC on Educational Technologies. In D. HernándezLeo, T. Ley, R. Klamma, \& A. Harrer (Eds.), Scaling up Learning for Sustained Impact. 8th European Conference, on Technology Enhanced Learning, EC-TEL 2013, Paphos, Cyprus, September 17-21, 2013. Proceedings (Vol. 8095, pp. 5-18). Berlin Heidelberg: Springer.

Alier Forment, M., Casany Guerrero, M. J., Conde González, M. Á., García-Peñalvo, F. J., \& Severance, C. (2010). Interoperability for LMS: the missing piece to become the common place for e-learning innovation. International Journal of Knowledge and Learning (IJKL), 6(2/3), 130-141. doi:10.1504/ IJKL.2010.034749

Baepler, P., \& Murdoch, C. J. (2010). Academic Analytics and Data Mining in Higher Education. International Journal for the Scholarship of Teaching and Learning, 4(2). Retrieved from http://digitalcommons. georgiasouthern.edu/ij-sotl/vol4/iss2/17

Berlanga, A. J., \& García-Peñalvo, F. J. (2004). Towards adaptive learning designs. 
In P. DeBra \& W. Nejdl (Eds.), Adaptive un MOOC y su comunidad de aprendizaje a Hypermedia and Adaptive Web-Based través de actividades. In Á. Fidalgo Blanco, Systems, Proceedings (Vol. 3137, pp. 372- M. L. Sein-Echaluce Lacleta, \& F. J. García375). Berlin: Springer. Peñalvo (Eds.), La Sociedad del Aprendizaje. Actas del III Congreso Internacional sobre

Berlanga, A. J., \& García-Peñalvo, F. Aprendizaje, Innovación y Competitividad. J. (2005a). IMS LD reusable elements CINAIC 2015 (14-16 de Octubre de 2015, for adaptive learning designs. Journal of Madrid, España) (pp. 635-640). Madrid, Interactive Media in Education, 11. Retrieved Spain: Fundación General de la Universidad from http://jime.open.ac.uk/article/2005-11/282 Politécnica de Madrid.

Berlanga, A. J., \& García-Peñalvo, F. J. Cabero, J. (2015). Visiones educativas sobre (2005b). Learning Technology Specifications: los MOOC. RIED, 18(2), 39-60.

Semantic Objects for Adaptive Learning

Environments. International Journal of Calvo de León, R. (2015). Recensión de la Learning Technology, 1(4), 458-472. doi: Tesis Doctoral: Adaptación de la legislación 10.1504/IJLT.2005.007155 a la Residencia "Gregorio Santiago" de Burgos de 1990 a 2000. Education in the Berlanga, A. J., \& García-Peñalvo, F. Knowledge Society, 16(4), 158-161. http:// J. (2008). Learning Design in Adaptive dx.doi.org/10.14201/eks2015164158161

Educational Hypermedia Systems. Journal of Universal Computer Science, 14(22), 3627- Castaño Garrido, C., Maiz, I., \& Garay Ruiz, 3647. doi:10.3217/jucs-014-22-3627 U. (2015). Diseño, motivación y rendimiento en un curso MOOC cooperativo. Comunicar,

Borrás Gené, O., Martínez-Núñez, M., \& 44, 19-26. doi:http://dx.doi.org/10.3916/C44-2015Fidalgo Blanco, Á. (2014). Gamification 02 in MOOC: Challenges, opportunities and proposals for advancing MOOC model. In Christensen, C. M., \& Weise, M. R. F. J. García-Peñalvo (Ed.), Proceedings of (2014, May 09). MOOCs' disruption the Second International Conference on is only beginning. The Boston Globe. Technological Ecosystems for Enhancing Retrieved from https://www.bostonglobe. Multiculturality (TEEM'14) (pp. 215-220). com/opinion/2014/05/09/moocs-disruption-onlyNew York, NY, USA: ACM. beginning/S2VlsXpK6rzRx4DMrS4ADM/story.html

Borrás-Gené, O., Martínez-Núñez, M., \& Conde, M. Á., García-Peñalvo, F. J., Fidalgo Blanco, Á. (2015). Gamificación de Rodríguez-Conde, M. J., Alier, M., Casany, 
M. J., \& Piguillem, J. (2014). An evolving Learning Management System for new educational environments using 2.0 tools. Interactive Learning Environments, 22(2) 188-204. doi:10.1080/10494820.2012.745433

Farmer, J. (2013). MOOCs: A Disruptive Innovation or Not? Retrieved from http:// mfeldstein.com/moocs-a-disruptive-innovationor-not/

Fernández-Pampillón Cesteros, A. M., Domínguez Romero, E., \& Armas Ranero, I. (2013). Análisis de la evolución de los Repositorios Institucionales de material educativo digitaldelasuniversidadesespañolas. RELATEC. Revista Latinoamericana de Tecnología Educativa, 12(2), 11-25.

Fidalgo, Á., Sein-Echaluce Lacleta, M. L., \& García-Peñalvo, F. J. (2013). MOOC cooperativo. Una integración entre cMOOC y xMOOC. In Á. Fidalgo Blanco \& M. L. Sein-Echaluce Lacleta (Eds.), Actas del II Congreso Internacional sobre Aprendizaje, Innovación y Competitividad, CINAIC 2013 (Madrid, 6-8 de noviembre de 2013) (pp. 481486). Madrid, España: Fundación General de la Universidad Politécnica de Madrid. Fidalgo Blanco, Á., García-Peñalvo, F. la Universidad Politécnica de Madrid. J., \& Sein-Echaluce Lacleta, M. L. (2013). A methodology proposal for developing Fidalgo-Blanco, Á. (2012). Desarrollo de adaptive cMOOC. In F. J. García-Peñalvo un sistema de gestión de conocimiento (Ed.), Proceedings of the First International para facilitar la aplicación, en contextos Conference on Technological Ecosystems for formativos, de las mejores prácticas de

Enhancing Multiculturality (TEEM'13) (pp. 553-558). New York, NY, USA: ACM.

Fidalgo Blanco, Á., Sein-Echaluce Lacleta, M. L., \& García-Peñalvo, F. J. (2015a). La Sociedad del Aprendizaje. Actas del III Congreso Internacional sobre Aprendizaje, Innovación y Competitividad. CINAIC 2015 (14-16 de Octubre de 2015, Madrid, España). Madrid: Fundación General de la Universidad Politécnica de Madrid.

Fidalgo Blanco, Á., Sein-Echaluce Lacleta, M. L., \& García-Peñalvo, F. J. (2015b). Methodological Approach and Technological Framework to break the current limitations of MOOC model. Journal of Universal Computer Science, 21(5), 712-734.

Fidalgo Blanco, Á., Sein-Echaluce Lacleta, M. L., García-Peñalvo, F. J., \& PinillaMartínez, J. (2015). BRACO: Buscador de Recursos Académicos Colaborativos. In Á. Fidalgo Blanco, M. L. Sein-Echaluce Lacleta, \& F. J. García-Peñalvo (Eds.), La Sociedad del Aprendizaje. Actas del III Congreso Internacional sobre Aprendizaje, Innovación y Competitividad. CINAIC 2015 (14-16 de Octubre de 2015, Madrid, España) (pp. 469474). Madrid, Spain: Fundación General de 
innovación docente (EA2011-0035). Retrieved from http://138.4.83.162/mec/ayudas/ repositorio/20121205163351EA2011-0035.pdf

Fidalgo-Blanco, Á., Balbín, A., Lerís, D., \& Sein-Echaluce, M. L. (2011). Repository of good practices applied to higher education in engineering Proceedings of Promotion and Innovation with New Technologies in Engineering Education (FINTDI), 5-6 May 2011, Teruel, Spain (pp. 1-7). EEUU: IEEE.

Fidalgo-Blanco, Á., Lerís, D., Sein-Echaluce, M. L., \& García-Peñalvo, F. J. (2013). Indicadores para el seguimiento y evaluación de la competencia de trabajo en equipo a través del método CTMTC. In Á. Fidalgo Blanco \& M. L. Sein-Echaluce Lacleta (Eds.), Actas del II Congreso Internacional sobre Aprendizaje, Innovación y Competitividad, CINAIC 2013 (pp. 280-285). Madrid, España: Fundación General de la Universidad Politécnica de Madrid.

Fidalgo-Blanco, Á., \& Ponce, J. (2011). Método CSORA: La búsqueda de conocimiento. Arbor: Ciencia, pensamiento y cultura, 187(No Extra_3), 51-66. doi: 10.3989/arbor.2011.Extra-3n3128

Fidalgo-Blanco, Á., Sein-Echaluce Lacleta, M. L., Lerís, D., \& García-Peñalvo, F. J. (2013). Sistema de Gestión de Conocimiento para la aplicación de experiencias de innovación educativa en la formación. In Á. Fidalgo Blanco \& M. L. Sein-Echaluce Lacleta (Eds.),
Actas del II Congreso Internacional sobre Aprendizaje, Innovación y Competitividad, CINAIC 2013 (pp. 750-755). Madrid, Spain: Fundación General de la Universidad Politécnica de Madrid.

Fidalgo-Blanco, Á., Sein-Echaluce, M. L., \& García-Peñalvo, F. J. (2014). Knowledge Spirals in Higher Education Teaching Innovation. International Journal of Knowledge Management, 10(4), 16-37. doi:10.4018/ijkm.2014100102

Fidalgo-Blanco, Á., Sein-Echaluce, M. L., \& García-Peñalvo, F. J. (2015). Epistemological and ontological spirals: From individual experience in educational innovation to the organisational knowledge in the university sector. Program: Electronic library and information systems, 49(3), 266-288. doi:http://dx.doi.org/10.1108/PROG-06-20140033

García-Holgado, A., \& García-Peñalvo, F. J. (2013). The evolution of the technological ecosystems: An architectural proposal to enhancing learning processes. In F. J. GarcíaPeñalvo (Ed.), Proceedings of the First International Conference on Technological Ecosystems for Enhancing Multiculturality (TEEM'13) (Salamanca, Spain, November 14-15, 2013) (pp. 565-571). New York, NY, USA: ACM.

García-Holgado, A., \& García-Peñalvo, F. J. (2014). Architectural pattern for the 
definition of eLearning ecosystems based on Open Source developments. In J. L. Sierra-Rodríguez, J. M. Dodero-Beardo, \& D. Burgos (Eds.), Proceedings of 2014 International Symposium on Computers in Education (SIIE), Logrono, La Rioja, Spain, 12-14 Nov. 2014 (pp. 93-98). USA: Institute of Electrical and Electronics Engineers.

García-Holgado, A., García-Peñalvo, F. J., Hernández-García, Á., \& Llorens-Largo, F. (2015). Analysis and Improvement of Knowledge Management Processes in Organizations Using the Business Process Model Notation. In D. Palacios-Marqués, D. Ribeiro Soriano, \& K. H. Huarng (Eds.), New Information and Communication Technologies for Knowledge Management in Organizations. 5th Global Innovation and Knowledge Academy Conference, GIKA 2015, Valencia, Spain, July 14-16, 2015, Proceedings (pp. 93-101). Switzerland: Springer International Publishing.

García-Peñalvo, F. J. (2015). Entrepreneurial and problem solving skills in software engineers. Journal of Information Technology Research, 8(3), iv-vi.

García-Peñalvo, F. J., Cruz-Benito, J., Conde, M. Á., \& Griffiths, D. (2014). Virtual placements for informatics students in open source business across Europe 2014 IEEE Frontiers in Education Conference Proceedings (October 22-25, 2014 Madrid, Spain) (pp. 2551-2555). USA: IEEE.
García-Peñalvo, F. J., Cruz-Benito, J., Conde, M. Á., \& Griffiths, D. (2015). Semester of Code: Piloting Virtual Placements for Informatics across Europe Proceedings of Global Engineering Education Conference, EDUCON 2015. Tallinn, Estonia, 18-20 Mach 2015 (pp. 567-576). USA: IEEE.

García-Peñalvo, F. J., Cruz-Benito, J., Griffiths, D., \& Achilleos, A. P. (2015a). Tecnología al servicio de un proceso de gestión de prácticas virtuales en empresas: Propuesta y primeros resultados del Semester of Code. IEEE VAEP-RITA, 3(1), 52-59.

García-Peñalvo, F. J., Cruz-Benito, J., Griffiths, D., \& Achilleos, A. P. (2015b). Virtual placements management process supported by technology: Proposal and firsts results of the Semester of Code. IEEE Revista Iberoamericana de Tecnologías del Aprendizaje (IEEE RITA).

García-Peñalvo, F. J., Cruz-Benito, J., Griffiths, D., Sharples, P., Willson, S., Johnson, M., Papadopoulos, G. A., Achilleos, A. P., Alier, M., Galanis, N., Conde, M. Á., Pessot, E., Elferink, R., Veenendaal, E., \& Lee, S. (2014). Developing Win-Win Solutions for Virtual Placements in Informatics: The VALS Case. In F. J. García-Peñalvo (Ed.), Proceedings of the Second International Conference on Technological Ecosystems for Enhancing Multiculturality (TEEM'14) (pp. 733-738). New York, USA: ACM. 
García-Peñalvo, F. J., Fidalgo Blanco, Á., \& Sein-EchaluceLacleta,M.L.(2015). Tendencias en Innovación Educativa. Conference at the III Congreso Internacional sobre Aprendizaje, Innovación y Competitividad (CINAIC 2015), Madrid, España. http://gredos.usal.es/ jspui/handle/10366/126559

García-Peñalvo, F. J., Hernández-García, Á., Conde-González, M. Á., Fidalgo-Blanco, Á., Sein-Echaluce Lacleta, M. L., AlierForment, M., Llorens-Largo, F., \& IglesiasPradas, S. (2015a). Learning services-based technological ecosystems. In G. R. Alves \& M. C. Felgueiras (Eds.), Proceedings of the Third International Conference on Technological Ecosystems for Enhancing Multiculturality (TEEM'15) (Porto, Portugal, October 7-9, 2015) (pp. 467-472). New York, USA: ACM.

García-Peñalvo, F. J., Hernández-García, Á., Conde-González, M. Á., Fidalgo-Blanco, Á., Sein-Echaluce Lacleta, M. L., AlierForment, M., Llorens-Largo, F., \& IglesiasPradas, S. (2015b). Mirando hacia el futuro: Ecosistemas tecnológicos de aprendizaje basados en servicios. In Á. Fidalgo Blanco, M. L. Sein-Echaluce Lacleta, \& F. J. GarcíaPeñalvo (Eds.), La Sociedad del Aprendizaje. Actas del III Congreso Internacional sobre Aprendizaje, Innovación y Competitividad. CINAIC 2015 (14-16 de Octubre de 2015, Madrid, España) (pp. 553-558). Madrid, Spain: Fundación General de la Universidad Politécnica de Madrid.
García-Peñalvo, F. J., Merlo-Vega, J. A., Ferreras-Fernández, T., Casaus-Peña, A., Albás-Aso, L., \& Atienza-Díaz, M. L. (2010). Qualified Dublin Core Metadata Best Practices for GREDOS. Journal of Library Metadata, 10(1), 13-36. doi:http://dx.doi. org/10.1080/19386380903546976

García-Peñalvo, F. J., Sein-Echaluce Lacleta, M. L., \& Fidalgo-Blanco, Á. (2015). Educational Innovation Management. A Case Study at the University of Salamanca. In G. R. Alves \& M. C. Felgueiras (Eds.), Proceedings of the Third International Conference on Technological Ecosystems for Enhancing Multiculturality (TEEM'15) (Porto, Portugal, October 7-9, 2015) (pp. 151-158). New York, USA: ACM.

García-Peñalvo, F. J., \& Seoane-Pardo, A. M. (2015). Una revisión actualizada del concepto de eLearning. Décimo Aniversario. Education in the Knowledge Society, 16(1), 119-144. doi:http://dx.doi.org/10.14201/ eks2015161119144

Gómez-Aguilar, D. A., García-Peñalvo, F. J., \& Therón, R. (2014). Analítica Visual en eLearning. El Profesional de la Información, 23(3), 236-245.

Gómez-Aguilar, D. A., Hernández-García, Á., García-Peñalvo, F. J., \& Therón, R. (2015). Tap into visual analysis of customization of grouping of activities in eLearning. Computers in Human Behavior, 47, 60-67. 
doi:http://dx.doi.org/10.1016/j.chb.2014.11.001

Gómez-Díaz, R., \& García-Rodríguez, Recuperación de Objetos de Aprendizaje de A. (2015). APPrender a leer y escribir: aplicaciones para el aprendizaje de la lectoescritura. Education in the Knowledge Society, 16(4), 118-137. http://dx.doi. org/10.14201/eks2015164118137

Lerís, D., \& Sein-Echaluce, M. L. (2011). La personalización del aprendizaje: Un objetivo del paradigma educativo centrado en el aprendizaje. Arbor, 187(Extra_3), 123-134. doi:10.3989/arbor.2011.Extra-3n3135

Lerís López, D., Vea Muniesa, F., \& Velamazán Gimeno, Á. (2015). Aprendizaje adaptativo en Moodle: Tres casos prácticos. Education in the Knowledge Society, 16(4), 138-157. http://dx.doi.org/10.14201/eks2015164138157

Llorens, F., Molina, R., Compañ, P., \& Satorre, R. (2014). Technological Ecosystem for Open Education. In R. Neves-Silva, G. A. Tsihrintzis, V. Uskov, R. J. Howlett, \& L. C. Jain (Eds.), Smart Digital Futures 2014. (Vol. 262, pp. 706-715): IOS Press.

López, C., García-Peñalvo, F., \& Pernías, P. (2005). Desarrollo de Repositorios de Objetos de Aprendizaje a través de la Reutilización de los Metadatos de una Colección Digital: De Dublin Core a IMS. RED. Revista de Educación a Distancia, IV(Número monográfico II). Retrieved from http://www. um.es/ead/red/M2

Morales, E. M., Gil, A. B., \& GarcíaPeñalvo, F. J. (2007). Arquitectura para la Calidad en Repositorios Distribuidos. In F. Gutiérrez Vela \& P. Paderewski Rodriguez (Eds.), Actas del $5^{\text {o }}$ Taller en Sistemas Hipermedia Colaborativos y Adaptativos, SHCA 2007 (Vol. 1, pp. 31-38). Zaragoza, España.

Morales, E. M., Gómez-Aguilar, D., \& García-Peñalvo, F. J. (2008). HEODAR: Herramienta para la Evaluación de Objetos Didácticos de Aprendizaje Reutilizables. In J. Á. Velázquez-Iturbide, F. J. García-Peñalvo, \& A. B. Gil (Eds.), Actas del X Simposio Internacional de Informática Educativa - SIIE'08 Salamanca, España: Ediciones Universidad de Salamanca.

Salzberg, S. (2015). How Disruptive Are MOOCs? Hopkins Genomics MOOC Launches In June. Forbes. Retrieved from http://www. forbes.com/sites/stevensalzberg/2015/04/13/ how-disruptive-are-moocs-hopkins-genomicsmooc-launches-in-june/

Sein-Echaluce Lacleta, M. L., Fidalgo Blanco, Á., \& García-Peñalvo, F. J. (2014). Buenas prácticas de Innovación Educativa: Artículos seleccionados del II Congreso Internacional sobre Aprendizaje, Innovación y Competitividad, CINAIC 2013. RED. Revista de Educación a Distancia, 44. Retrieved from http://www.um.es/ead/red/44/ 
Sein-Echaluce Lacleta, M. L., Fidalgo-Blanco, de La Rioja (UNIR).

Á., García-Peñalvo, F. J., \& Conde-González,

M. Á. (2015). A knowledge management system to classify social educational resources within a subject using teamwork techniques.

In P. Zaphiris \& I. Ioannou (Eds.), Learning and Collaboration Technologies. Second

Sierra Rodríguez, J. L., \& García-Peñalvo, F. J. (2015). Informática Educativa y Educación en Informática. Education in the Knowledge Society, 16(4), 25-31. http:// International Conference, LCT 2015, Held as Part of HCI International 2015, Los Angeles, CA, USA, August 2-7, 2015, Proceedings (pp. 510-519). Switzerland: Springer International Publishing.

dx.doi.org/10.14201/eks20151642531

Sonwalkar, N. (2013). The First Adaptive MOOC: A Case Study on Pedagogy Framework and Scalable Cloud Architecture-Part I. MOOCs Forum, 1(P), 22-29. doi:10.1089/ mooc.2013.0007

Sein-Echaluce, M. L., Lerís, D., FidalgoBlanco, Á., \& García-Peñalvo, F. J. (2013). Knowledge management system for applying Taamallah, A., \& Khemaja, M. (2015). educational innovative experiences. In F. J. García-Peñalvo (Ed.), Proceedings of the First International Conference on Technological Ecosystems for Enhancing Multiculturality (TEEM'13) (pp. 405-410). New York, USA: ACM.

Weise, M. R., \& Christensen, C. M. (2014). Hire Education. Mastery, modularization,

Sierra Rodríguez, J. L., Dodero Beardo, J. and the workforce revolution. EEUU: Clayton M., \& Burgos, D. (2014a). International Christensen Institute.

Symposium on Computers in Education (SIIE), 2014. USA: IEEE.

Wing, J. M. (2006). Computational Thinking. Communications of the ACM, 49(3), 33-35.

Sierra Rodríguez, J. L., Dodero Beardo, J. M., \& Burgos, D. (2014b). XVI Simposio Internacional de Informática Educativa (SIIE'14). Acceso masivo y universal para un aprendizaje a lo largo de la vida (12-14 Zapata-Ros, M. (2015). Pensamiento computacional: Una nueva alfabetización digital. RED, Revista de Educación a distancia, 46. Retrieved from http://www. de Noviembre de 2014, Logroño, La Rioja, um.es/ead/red/46/zapata.pdf España). España: Universidad Internacional 